He may be intended at I089:pen, where the word pasea.

\title{
IV. ON THE ARAMAIC DiALECTS CITED IN THE LEXICON
}

It is obvious that the popular dialects of Babylon would be especially well-known to the lexicographers, who resided in Baghdad; thus it is not surprising that these are often cited in the lexicons of Bar 'Ali and Bar Bahlul. Thus, it will be helpful to give an exposition of these at the beginning.

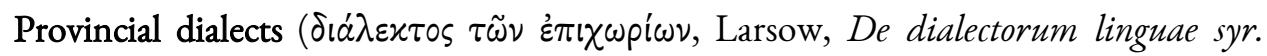

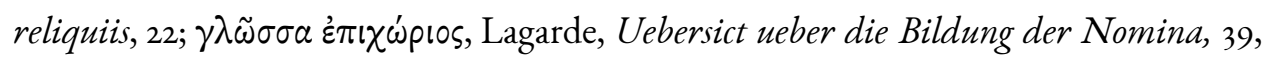
note 3, ritir rel, I88:10, 228:3, 438:4, 507:20, 575:10; 875:5, 2030:13, 2077:6. This seems to refer to the Aramaic speech of the people of southern Babylon and Arabic Iraq, cf. 507:20, revir ar ridir nel "the provincial language or Arabic."

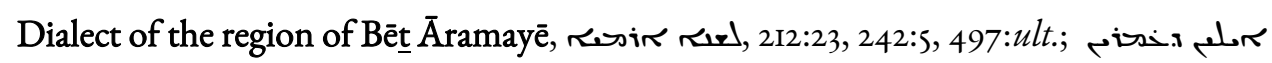

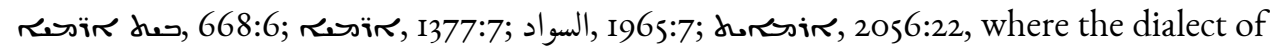
Mesena [الميسان] and now called by the Arabs Sawād al-Küfa (سواد الكوفة), see Noeldeke, Z. D. M. G., $\mathrm{XXV}, \mathrm{II} 4-\mathrm{II} 5$.

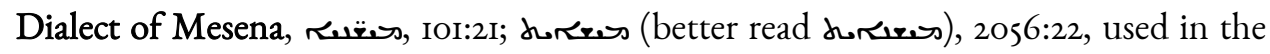
region of Mesena, which is called by the Arabs Sawād al-Bașrā; cf. Noeldeke, cited (in the previous entry).

Dialect of Qatar (on the Arab shore of the Persian Gulf), 几 ఒ

Dialect of Mațarta (Arabic مطيرة, near Samarra?), Rhibsid, 1752:12.

Dialect of Tagrīt or Țirhān, which was most familiar to the ears of Bar Bahlul, who indeed hailed from the province of Tirhān (also Ṭinhān), as we said above on p. x. The usages of this dialect are often related in the (following) ways: , mitb, a mb ad

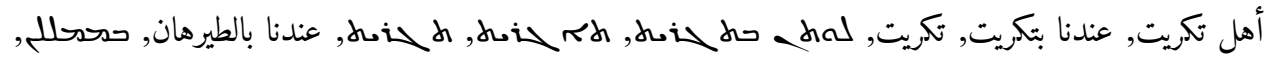
- mit sib; out of many (examples), we give: I06:15, I92:2, 45I:I, 498:I4, 503:7, 514:24, 536:9, 733:I0, 751:5, 768:18, 820:I2, I392:II, I745:I2, I784:19, I852:3, I855:pen., I891:7, I906:I8, I916:I8, I937:8, 1943:7, 1997:7, 1999:II, 2048:6, 2075:8. The Arabs called this region Bārimma (بارمّمَ", in the mountain of Hemrīn, near Takrît), as is clear from the gloss 867:I7: عندنا ببارمّا

Dialect of the Higher Regions, اللغة العالية, ممiتسم إللد, I54:2I, 
265:4, 475:I, 520:I0, 768:I8, 769:I2, 77I:I, 773:2I, 900:25, 981:2I, I355:20, I45I:I0, I752:II; this is the mountainous region beyond the river Tigris, situated to the south of the province of Bēt Garmay, cf. the glosses 475:I and 768:I8, where is read: حلع - miv. "in the dialect of the Highlands and that of Tirhān." This dialect is contrast-

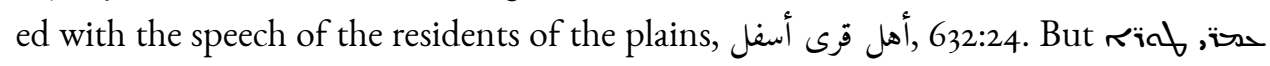
"of the mountains," 732:14, seems to designate those resident in the region of the city of Amid (Diyarbakir).

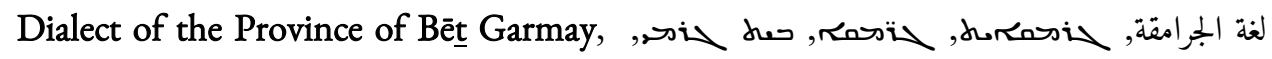
resil rel, 731:13, 741:26, 775:15, 919:17, 977:21, 1960:4. The province of Bêth Garmay, or Garama, was situated beyond the river Tigris to the south of the Lesser Zab river.

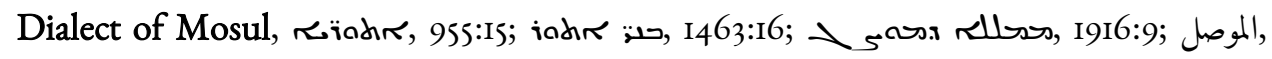
192:2.

Dialect of the Province of Diyār Rabī'a (between Mosul and Reš 'Aynā), ديار ريعة, I392:16; 1965:7.

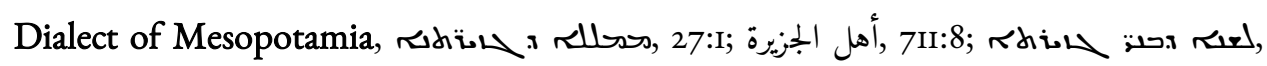

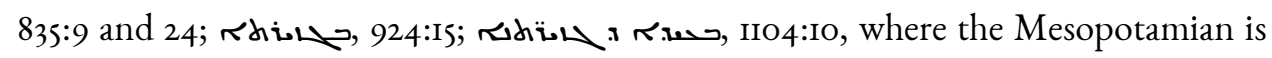
contrasted with the Babylonian.

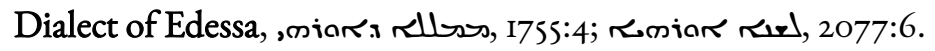

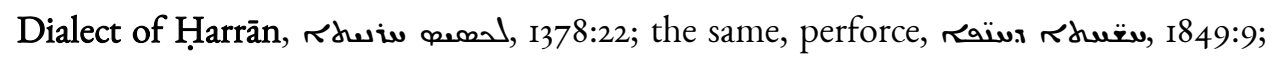
cf. The Book of the Harrānenes, p. xvii, above.

Dialect of Samosata, 575:15. لغة أهل شمشاط,

Dialect of Syria, أهل الشام, في الشام, لغة الشام, 732:6, 1917:IO, 1932:4, 1965:6.

Dialect of Palestine, 668:4.

\section{DESCRIPTION OF THE MANUSCRIPTS OF THE LEXICON}

The manuscripts that we have used in editing the lexicon are here described extensively. It will be sufficient to note others that were of no utility for us. We shall begin with the description of the manuscripts that were copied or prepared before the others. 